\title{
Article \\ One-Time Acidification of Slurry: What Is the Most Effective Acid and Treatment Strategy?
}

\author{
Veronika Overmeyer ${ }^{1, *(\mathbb{C}}$, Anita Kube ${ }^{1}$, Joachim Clemens ${ }^{2}$, Wolfgang Büscher ${ }^{1}\left(\mathbb{D}\right.$ and Manfred Trimborn ${ }^{1}(\mathbb{D}$ \\ 1 Institute of Agricultural Engineering, University of Bonn, 53115 Bonn, Germany; a.kube@uni-bonn.de (A.K.); \\ buescher@uni-bonn.de (W.B.); m.trimborn@uni-bonn.de (M.T.) \\ 2 SF-Soepenberg GmbH, 46569 Hünxe, Germany; j.clemens@soepenberg.com \\ * Correspondence: overmeyer@uni-bonn.de; Tel.: +49-228-73-2837
}

Citation: Overmeyer, V.; Kube, A.; Clemens, J.; Büscher, W.; Trimborn, M. One-Time Acidification of Slurry: What Is the Most Effective Acid and Treatment Strategy? Agronomy 2021, 11, 1319. https://doi.org/10.3390/ agronomy11071319

Academic Editors: David Fangueiro and José L. S. Pereira

Received: 10 May 2021

Accepted: 26 June 2021

Published: 28 June 2021

Publisher's Note: MDPI stays neutral with regard to jurisdictional claims in published maps and institutional affiliations.

Copyright: (c) 2021 by the authors. Licensee MDPI, Basel, Switzerland. This article is an open access article distributed under the terms and conditions of the Creative Commons Attribution (CC BY) license (https:// creativecommons.org/licenses/by/ $4.0 /)$.

\begin{abstract}
Acidification of slurry is a common practice to reduce ammonia and methane emissions. Sulfuric acid is usually used for this process. However, this has been criticized due to the high sulfur input into soils. Therefore, the objective of this study is to show the effectiveness of a one-time acidification with alternative acids also in combination with other treatment strategies. The amount of acid as well as the change of $\mathrm{pH}$ value during storage were investigated. For most variants, a strong $\mathrm{pH}$ increase occurred within the first ten days after acidification. Mineral acids (sulfuric or hydrochloric acid) resulted in a lower $\mathrm{pH}$ increase compared to organic acids (lactic, acetic, and citric acid). Under anaerobic storage conditions, the $\mathrm{pH}$ remained significantly lower. The addition of glucose before acidification resulted in lower $\mathrm{pH}$ values during the first week, but in the long term, the conversion of glucose to carbonate led to higher $\mathrm{pH}$ values. A previous separation process was able to reduce the amount of acid. Although the $\mathrm{pH}$ increase was not that strong in the first days after acidification, it was much faster and stronger afterwards due to the lower buffer capacity in the separated slurry. A long-term $\mathrm{pH}$ reduction was achieved by acidification to $\mathrm{pH}$ 3.0, but this was associated with an increased amount of acid. On the basis of the results, a combination of organic acids with anaerobic storage can be recommended as an alternative to sulfuric acid.
\end{abstract}

Keywords: manure management; mineral acids; organic acids; anaerobic storage; separation; addition of glucose

\section{Introduction}

The agricultural sector contributes to gaseous emissions [1-3]. Methane $\left(\mathrm{CH}_{4}\right)$ is a harmful gas that substantially affects climate change and has a global warming potential 25 times higher than carbon dioxide [4]. The storage of slurry leads to methane emissions from livestock production $[5,6]$. These can be reduced by acidification, solid-liquid separation, or dilution of the slurry, whereas covering may even increase methane emissions [5]. Ammonia $\left(\mathrm{NH}_{3}\right)$ is a major problem in slurry management due to its impact on the environment such as eutrophication, soil acidification, and the release of fine particulate aerosols or nitrous oxide emissions [7-9]. Ammonia emissions may occur in barns, when stored, or during the land application of slurry [10]. There are various techniques for reducing ammonia emissions such as covering or acidification $[2,5]$.

The equilibrium between $\mathrm{NH}_{4}{ }^{+} \rightleftharpoons \mathrm{NH}_{3}+\mathrm{H}^{+}$is strongly $\mathrm{pH}$-sensitive. As the $\mathrm{pH}$ is lowered by the addition of an acid, the equilibrium changes from the volatile nonionized form $\mathrm{NH}_{3}$ to the non-volatile ionized form $\mathrm{NH}_{4}{ }^{+}[11,12]$. At a $\mathrm{pH}$ value of 6.0, the total ammonia nitrogen is present as ammonium [10], and therefore no more ammonia can be released. The $\mathrm{pH}$ value of slurry is reduced to 5.5 during in-house acidification in Denmark $[13,14]$. Acidified slurry ( $\mathrm{pH} 5.5$ ) leads to a reduction in $\mathrm{NH}_{3}$ and $\mathrm{CH}_{4}$ emissions by 75 and $61 \%$, respectively [15]. It can be assumed that the longer the $\mathrm{pH}$ value of the slurry is kept at a low $\mathrm{pH}$ value, the greater the effect on the emissions reduction [16]. Lowering the $\mathrm{pH}$ value of slurry below 6.0 and 5.5 is sufficient to reduce 
$\mathrm{NH}_{3}$ emissions after soil application by at least $80 \%$ from pig or rather dairy cow slurry [17]. Nyord et al. [18] observed a reduction in $\mathrm{NH}_{3}$ emissions by about 70 and $65 \%$, respectively, in the land application of barn acidified ( $\mathrm{pH} 5.9-6.3$ ) and field acidified ( $\mathrm{pH}$ 6.1-6.7) slurry. By acidifying swine slurry to a $\mathrm{pH}$ value of 5.3 , ammonia emissions were reduced by $80 \%$ on a laboratory scale over $96 \mathrm{~h}$ [19]. Methane emissions are also effectively reduced at a $\mathrm{pH}$ value below $6.0[20,21]$. The acidification of slurry can be carried out in-house, in storage, or during land application. Foaming may occur during acidification [10]. The widespread establishment of acidification techniques can only be guaranteed if they are economically viable for farmers [22], therefore an optimized addition of acid to the slurry is of great importance. The use of high amounts of acid and large quantities of acidified slurry during land application can lead to a reduction of the $\mathrm{pH}$ value in the soil $[23,24]$. Furthermore, the application of acidified slurry can influence $\mathrm{pH}$-sensitive biological soil processes [25]. Therefore, a $\mathrm{pH}$ reduction in the soil should be compensated by liming [23,24].

There are different acids that can be used for acidification of slurry [26-28]. Sulfuric acid is usually used for the acidification of slurry [10]. The acidification costs for sulfuric acid are lower as compared with other acids [10,29]. However, the use of sulfuric acid can lead to over fertilization with sulfur during subsequent land applications [30]. Additionally, hydrogen sulfide and unpleasant odors can be produced [28,30,31]. The use of strong acids such as sulfuric acid requires specific safety requirements [26,30,32]. Furthermore, gypsum may be formed in some types of concrete at high sulfate concentrations in acidified slurry [33]. This can be a problem especially for concrete slurry storage tanks. Due to these limitations, other acids should be considered which have equal effectiveness as sulfuric acid. Additional slurry or storage treatments to reduce the amount of sulfuric acid would also be possible.

Organic acids are often weak, and therefore large quantities are needed to reach the target $\mathrm{pH}$ value [30]. In addition, organic acids are expected to be degraded faster, which can lead to foam formation and the release of carbon dioxide [30]. However, they may offer an opportunity, in particular for organic farming, for example, as they may be permitted for acidification of slurry more easily than sulfuric acid [28].

Instead of adding acids to the slurry, the addition of easily degradable organic compounds such as sucrose, glucose, sugar beet residues, or brewing sugar can also be used, as the fermentation of these products contributes to the formation of organic acids, which in turn lead to a reduction in the $\mathrm{pH}$ value $[34,35]$.

Due to the buffer capacity in the slurry, the $\mathrm{pH}$ value may return to its initial $\mathrm{pH}$ value after acidification [28]. Possible reasons for an increase in $\mathrm{pH}$ value can be the degradation of volatile fatty acids (VFA), mineralization of organic nitrogen, or dissolution of carbonates [36-38]. Studies on acidification have shown that, depending on the type of slurry, around three to six weeks after slurry is acidified to a $\mathrm{pH}$ of 5.5 the $\mathrm{pH}$ increase is stable $[13,26,27]$.

Currently, we are not aware of any study that has investigated a wide range of different acids and treatments which may affect the $\mathrm{pH}$ development after acidification of slurry. In addition, the chemical transformation processes which explain the $\mathrm{pH}$ value development after acidification in the different treatments are often incomplete. These could be demonstrated by a one-time acidification process. With these results, however, it would be possible to acidify the slurry in a way that saves resources and protects the environment.

The aim of this study is to investigate the long-term stability of the $\mathrm{pH}$ value in slurry after a one-time acidification with different organic and mineral acids. Furthermore, the influence of anaerobic storage, the addition of glucose, or a previous separation process on the $\mathrm{pH}$ value of acidified slurry is described. In addition, changes in the $\mathrm{pH}$ value during the storage of slurry are observed starting from different target $\mathrm{pH}$ values. On the basis of these results, it can be estimated which treatment strategy is most effective for reducing and keeping the $\mathrm{pH}$ value of slurry at a low level with a one-time acidification process. Thus, an effective $\mathrm{pH}$ value reduction could be achieved and maintained even during 
long storage periods. This would have the advantage that a strong reduction in $\mathrm{NH}_{3}$ and $\mathrm{CH}_{4}$ emissions could be achieved during storage and land application. Furthermore, by comparing the different treatments during and after the acidification process, it would be possible to establish more efficient farm individual management strategies, especially to reduce the use of sulfuric acid.

\section{Materials and Methods}

\subsection{Sampling and Storage of Slurry}

In our investigation, we used dairy cow, fattening pig, and sow slurry. The choice of the three slurry types from different animal species, and thus also different feeding managements, considerably increased the variability of the ingredients such as dry residue, ammonium nitrogen, or acetic acid equivalent in the slurry samples. Since the slurry of the different animal species was not compared but the treatment strategies were compared, one sample per animal species was sufficient.

Approximately $10 \mathrm{~L}$ of slurry was taken from the respective animal housing at least one week before acidification. All variants were acidified on the same day. For each variant, $50 \mathrm{~g}$ of the slurry was diluted with $50 \mathrm{~g}$ deionized water. We had to dilute the slurry with deionized water because stirring undiluted slurry, especially with a high dry residue content, was not possible on a laboratory scale. By diluting the slurry, a homogenous distribution of the acid and an exact determination of the $\mathrm{pH}$ value and the amount of acid used could be guaranteed. The buffer effect of the deionized water was not considered because of its low ion content. The conversion processes and principles of action can also be detected in diluted slurry, as shown in previous studies [38]. The $\mathrm{pH}$ value and temperature of the slurry were both measured with the $\mathrm{pH}$ sensor 'InLab Expert Pro' (Mettler Toledo, OH, USA). The $\mathrm{pH}$ sensor was calibrated in accordance with the manufacturer's instructions. Samples were stirred before $\mathrm{pH}$ value measurement.

After acidification, the samples were stored in $250 \mathrm{~mL}$ sample bottles (height $119 \mathrm{~mm}$ and inner diameter $63 \mathrm{~mm}$, low density polyethylene) at $22.0 \pm 0.4{ }^{\circ} \mathrm{C}$ under aerobic conditions (except anaerobic variants, see Section 2.2) as the lids were laid on the sample bottles rather than screwed on tightly. This enabled potential gas exchange without strong evaporation losses. The $\mathrm{pH}$ value was measured every three to four days during the first three weeks. Thereafter, the $\mathrm{pH}$ value was recorded weekly. The acidified samples were stored for seven weeks, which was sufficient time to adequately assess the $\mathrm{pH}$ development of the different treatment strategies. The analysis of the three types of slurry were carried out by an external laboratory (AGROLAB Agrar und Umwelt GmbH, Sarstedt, Germany). The following parameters were analyzed: dry residue, total nitrogen $(\mathrm{N})$, ammonium nitrogen $\left(\mathrm{NH}_{4}-\mathrm{N}\right)$, phosphate $\left(\right.$ as $\left.\mathrm{P}_{2} \mathrm{O}_{5}\right)$, potassium $\left(\right.$ as $\left.\mathrm{K}_{2} \mathrm{O}\right)$, and the main volatile fatty acids (acetic acid, butyric acid, iso-butyric acid, valeric acid, iso-valeric acid, n-caproic acid). The acetic acid equivalent was determined from the volatile fatty acids. Each variant included three repetitions.

\subsection{Different Variants of Acidification}

The variants differed in terms of the type of acid, slurry, and different (previous) treatments (Table 1). Due to scientific background and own preliminary tests, the samples were acidified to the target $\mathrm{pH}$ value $5.5(+/-0.03 \mathrm{pH}$ units). While stirring, acid was titrated to the slurry with micropipettes $(0.5$ to $5 \mathrm{~mL})$. Additional acid was titrated when the $\mathrm{pH}$ value was stable.

The dairy cow slurry was acidified with the following organic acids: lactic acid $\left(\mathrm{C}_{3} \mathrm{H}_{6} \mathrm{O}_{3}\right)$, acetic acid $\left(\mathrm{CH}_{3} \mathrm{COOH}\right)$ and citric acid $\left(\mathrm{C}_{6} \mathrm{H}_{8} \mathrm{O}_{7}\right)$. As mineral acids sulfuric acid $\left(\mathrm{H}_{2} \mathrm{SO}_{4}\right)$ and hydrochloric acid $(\mathrm{HCl})$ were used. Acidification of the fattening pig and sow slurry was only carried out with lactic and sulfuric acid. 
Table 1. Overview of the variants depending on the type of acid, slurry, and (previous) treatment.

\begin{tabular}{|c|c|c|c|c|c|c|}
\hline \multirow[b]{2}{*}{ Treatment } & \multirow[b]{2}{*}{ Acid } & \multirow[b]{2}{*}{ Concentration } & \multirow[b]{2}{*}{$\mathrm{pKa}^{1}$} & \multicolumn{3}{|c|}{ Type of Slurry } \\
\hline & & & & Dairy Cow & Fattening Pig & Sow \\
\hline & & $\operatorname{mol~L}-1$ & & & & \\
\hline No Acidification & & & & $X$ & $X$ & $X$ \\
\hline \multirow{4}{*}{ Organic acid } & Lactic acid & 0.5 & 3.86 & $X$ & $x$ & $X$ \\
\hline & Acetic acid & 0.5 & 4.76 & $x$ & & \\
\hline & & & 3.13 & & & \\
\hline & Citric acid & 0.25 & $\begin{array}{c}4.76 \\
6.4\end{array}$ & $X$ & & \\
\hline \multirow[t]{2}{*}{ Mineral acid } & Sulfuric acid & 0.25 & $\begin{array}{l}-3.00 \\
-6.62 \\
\end{array}$ & $x$ & $x$ & $x$ \\
\hline & Hydrochloric acid & 0.5 & -7.00 & $x$ & & \\
\hline \multirow{2}{*}{$\begin{array}{l}\text { Storage under } \\
\text { anaerobic conditions }\end{array}$} & Sulfuric acid & 0.5 & $\begin{array}{l}-3.00 \\
-6.62\end{array}$ & $X$ & & \\
\hline & Lactic acid & 0.25 & 3.86 & $x$ & & \\
\hline Addition of glucose & Sulfuric acid & 0.25 & $\begin{array}{l}-3.00 \\
-6.62\end{array}$ & $X$ & $x$ & $X$ \\
\hline Separation & Sulfuric acid & 0.25 & $\begin{array}{l}-3.00 \\
-6.62\end{array}$ & $x$ & $x$ & \\
\hline $\mathrm{pH}$ value 4.5 & Sulfuric acid & 0.25 & $\begin{array}{l}-3.00 \\
-6.62\end{array}$ & $x$ & & \\
\hline $\mathrm{pH}$ value 3.0 & Sulfuric acid & 0.25 & $\begin{array}{l}-3.00 \\
-6.62\end{array}$ & $x$ & & \\
\hline
\end{tabular}

${ }^{1}$ Acid dissociation constant; $\mathrm{X}$ shows to which slurry the acid and (previous) treatment was applied.

In addition to aerobic storage, two variants (acidification of dairy cow slurry with sulfuric and lactic acid) were additionally stored under anaerobic conditions. Acidified samples were stored anaerobically in completely closed $500 \mathrm{~mL}$ sample bottles (height $152 \mathrm{~mm}$ and inner diameter $78 \mathrm{~mm}$, low density polyethylene). Such bottles may cope with small changes in pressure without leakages. We expected only small volume changes in the bottles because of temperature and ambient pressure changes. Gas formation due to anaerobic activities was supposed to be negligible because of the low $\mathrm{pH}$ value in the slurry. Directly after acidification as well as after each $\mathrm{pH}$ value measurement, the headspaces of the sample bottles were flushed with nitrogen $\left(\mathrm{N}_{2}\right)$ for $30 \mathrm{sec}$ (flow rate approximately $5.5 \mathrm{~L} \mathrm{~min}^{-1}$ ). Due to the opening of the sample bottles for $\mathrm{pH}$ measurement during storage, room air could enter the sample bottles. This air was expelled from the headspace of the sample bottle by flushing with nitrogen. In this way, an oxygen content $<0.1 \%$ could be realized in the sample bottles.

We investigated the influence of an easily degradable organic substance in combination with acid on the development of the $\mathrm{pH}$ value. Therefore, $2 \mathrm{~g}$ glucose $\left(\mathrm{C}_{6} \mathrm{H}_{12} \mathrm{O}_{6}\right)$ was dissolved in $10 \mathrm{~mL}$ deionized water and $0.5 \mathrm{~mL}$ of the solution was added to $50 \mathrm{~g}$ slurry (0.01 mol glucose $\mathrm{kg}^{-1}$ slurry). Then, the slurry was acidified with sulfuric acid. By adding glucose to the slurry, we also wanted to show the conversion process of easily fermentable carbohydrates in slurry during storage.

The influence of separation of the slurry on the $\mathrm{pH}$ value stability was tested. Therefore, dairy cow and fattening pig slurry were centrifuged $10 \mathrm{~min}$ at $4650 \mathrm{G}$ using an 'AvantiTM J-20 Centrifuge' (Beckman Coulter GmbH, Krefeld, Germany). The supernatant was passed through a sieve $(0.9 \mathrm{~mm}$ pore size) to separate floating components and then centrifuged again under the same settings. For this investigation, only the liquid phase was used. Hereafter the liquid phase is called 'separated slurry'. 
In addition to the acidification of dairy cow slurry to a $\mathrm{pH}$ value of 5.5 , other samples were acidified to $\mathrm{pH}$ values of 4.5 or 3.0 with sulfuric acid.

For every variant, the amount of acid was recorded to reach the target $\mathrm{pH}$ value. The alkalinity of the different types of slurry can be described by the amount of sulfuric acid used in the titration to $\mathrm{pH} 5.5$.

Because of capacity constraints, not every treatment strategy could be applied to every type of slurry. Therefore, the different treatment strategies were performed using the dairy cow slurry as an example, so that at least the tendency to weigh up the different acids and treatments for long-term $\mathrm{pH}$ reduction could be transferred to other types of slurry.

\subsection{Statistical Analysis}

Statistical analyses were done with IBM ${ }^{\circledR}$ SPSS $^{\circledR}$ Statistics, Version 25. The values represent mean values with standard deviation (means $\pm \mathrm{SD}$ ). One-way analysis of variance (ANOVA) was performed at a significance level of 0.05 to describe the differences in the amount of acid used for acidification. Hereafter, the Tukey's Honestly Significance Difference (HSD) was used.

If not mentioned separately, a mixed ANOVA was chosen to compare the $\mathrm{pH}$ values of the variants during storage after acidification. Then, the Tukey's honestly significance difference (HSD) was also applied. In the absence of variance homogeneity, the GamesHowell test was used. All tests were conducted at a significance level of 0.05 .

\section{Results}

\subsection{Amount of Acid}

The $\mathrm{pH}$ value of the dairy cow, fattening pig, and sow slurry before acidification was $7.10 \pm 0.05,7.04 \pm 0.07$, and $8.20 \pm 0.02$, respectively. Additional analyses of the slurries are given in Table 2.

Table 2. Characteristics of dairy cow, fattening pig and sow slurry (fresh material) before acidification process.

\begin{tabular}{ccccc}
\hline \multicolumn{1}{c}{ Ingredients } & & Dairy Cow & Fattening Pig & Sow \\
\hline Dry residue & $\%$ & 9.5 & 8.3 & 3.5 \\
$\mathrm{~N}$ & $\mathrm{~kg} \mathrm{~m}^{-3}$ & 4.12 & 6.24 & 7.76 \\
$\mathrm{NH}_{4}-\mathrm{N}$ & $\mathrm{kg} \mathrm{m}^{-3}$ & 2.05 & 4.08 & 6.83 \\
$\mathrm{P}_{2} \mathrm{O}_{5}$ & $\mathrm{~kg} \mathrm{~m}^{-3}$ & 1.48 & 3.83 & 2.16 \\
$\mathrm{~K}_{2} \mathrm{O}$ & $\mathrm{kg} \mathrm{m}^{-3}$ & 5.04 & 3.01 & 4.27 \\
Acetic acid & $\mathrm{g} \mathrm{kg}^{-1}$ & 6.3 & 9.2 & 0.09 \\
Propionic acid & $\mathrm{g} \mathrm{kg}^{-1}$ & 1.5 & 2.5 & $<0.05$ \\
Acetic acid equivalent $^{1}$ & $\mathrm{~g} \mathrm{~kg}^{-1}$ & 8.1 & 14 & $<0.10$ \\
pH value $^{2}$ & & 7.1 & 7.04 & 8.2 \\
\hline
\end{tabular}

${ }^{1}$ Acetic acid equivalents were calculated from the acetic, propionic, butyric, iso-butyric, valeric, iso-valeric, and n-caproic acids; ${ }^{2}$ Own investigation.

Depending on the type of acid and slurry, different amounts of acid were required to achieve the target $\mathrm{pH}$ value of 5.5 (Table 3). While approximately the same amount of lactic or sulfuric acid was required for acidification for the dairy cow and fattening pig slurry, more than three times this amount had to be used for the sow slurry to achieve the target $\mathrm{pH}$ value. This shows that the alkalinity was also highest in the sow slurry. For the acidification of the dairy cow slurry, significantly fewer moles of $\mathrm{H}^{+} \mathrm{kg}^{-1}$ slurry were used with lactic acid as compared with acetic, hydrochloric, and sulfuric acid. A previous separation process also resulted in a significantly lower amount of sulfuric acid which was needed to reduce the $\mathrm{pH}$ value to 5.5 . 
Table 3. Amount of acid required to decrease the $\mathrm{pH}$ to 5.5 if not indicated otherwise (means $\pm \mathrm{SD}, n=3)$.

\begin{tabular}{|c|c|c|c|c|c|c|c|}
\hline \multirow{3}{*}{ Treatment } & \multirow{3}{*}{ Acid } & \multicolumn{6}{|c|}{ Type of Slurry } \\
\hline & & \multicolumn{2}{|c|}{ Dairy Cow } & \multicolumn{2}{|c|}{ Fattening Pig } & \multicolumn{2}{|c|}{ Sow } \\
\hline & & $\mathrm{mL} \mathrm{kg}^{-1}$ Slurry & mol H $\mathrm{kg}^{+1}$ Slurry & $\mathrm{mL} \mathrm{kg}^{-1}$ Slurry & mol H $\mathrm{kg}^{-1}$ Slurry & mL kg ${ }^{-1}$ Slurry & $\mathrm{mol} \mathrm{H}^{+} \mathrm{kg}^{-1}$ Slurry \\
\hline Organic acid & $\begin{array}{l}\text { Lactic acid } \\
\text { Acetic acid } \\
\text { Citric acid }\end{array}$ & $\begin{array}{c}360 \pm 20 \\
300 \pm 0 \\
227 \pm 6\end{array}$ & $\begin{array}{c}0.09 \pm 0.005^{a, *} \\
0.15 \pm 0.000^{b} \\
0.11 \pm 0.003^{a b}\end{array}$ & $380 \pm 0$ & $0.10 \pm 0.000$ * & $1470 \pm 17$ & $0.37 \pm 0.004$ \\
\hline $\begin{array}{l}\text { Storage under } \\
\text { anaerobic conditions }\end{array}$ & $\begin{array}{l}\text { Lactic acid } \\
\text { Sulfuric acid }\end{array}$ & $\begin{array}{l}353 \pm 12 \\
290 \pm 10\end{array}$ & $\begin{array}{l}0.09 \pm 0.003^{a} \\
0.15 \pm 0.005^{b}\end{array}$ & & & & \\
\hline Addition of glucose & Sulfuric acid & $307 \pm 16$ & $0.15 \pm 0.008^{b, \ddagger}$ & $311 \pm 2$ & $0.16 \pm 0.001 \ddagger$ & $1169 \pm 12$ & $0.58 \pm 0.006$ \\
\hline Separation & Sulfuric acid & $233 \pm 12$ & $0.12 \pm 0.006^{\mathrm{ab}}$ & $170 \pm 0$ & $0.09 \pm 0.000^{+}$ & & \\
\hline $\mathrm{pH}$ value 4.5 & Sulfuric acid & $527 \pm 12$ & $0.26 \pm 0.006^{\mathrm{d}}$ & & & & \\
\hline
\end{tabular}

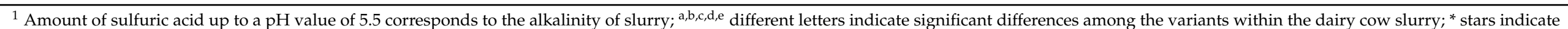

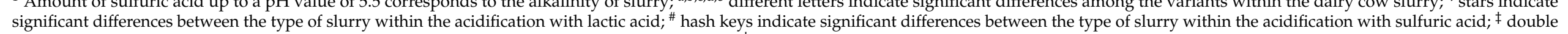
daggers indicate significant differences between the type of slurry within the addition of glucose; ${ }^{\dagger}$ daggers indicate significant differences between the type of slurry within the previous separation. 


\subsection{Organic and Mineral Acids}

Over a period of 48 days, the $\mathrm{pH}$ value of the dairy cow (DC, $\bullet$ ), fattening pig (FP, $\Delta)$ and sow $(\mathrm{S}, \mathbf{\square})$ slurry was measured every three to four days during the first three weeks of storage. Subsequently, the $\mathrm{pH}$ value was measured weekly. The slurries acidified by different acids (target $\mathrm{pH}$ value 5.5) are color coded in Figures 1-6. In addition, the treatments in the figures are distinguished by different line structures. Furthermore, the development of the $\mathrm{pH}$ value of the unacidified slurry during storage was determined. The related data are given in Supplementary Material Table S1-S6.

\subsubsection{Zero Treatments}

The $\mathrm{pH}$ values of the three slurries without acidification increased during storage (Figure 1 and Table S1). This increase was stronger for the dairy cow and fattening pig slurry as compared with the sow slurry, which already had a high initial $\mathrm{pH}$ value. The $\mathrm{pH}$ value increased more strongly within the first few days of the experiment (until day 16).

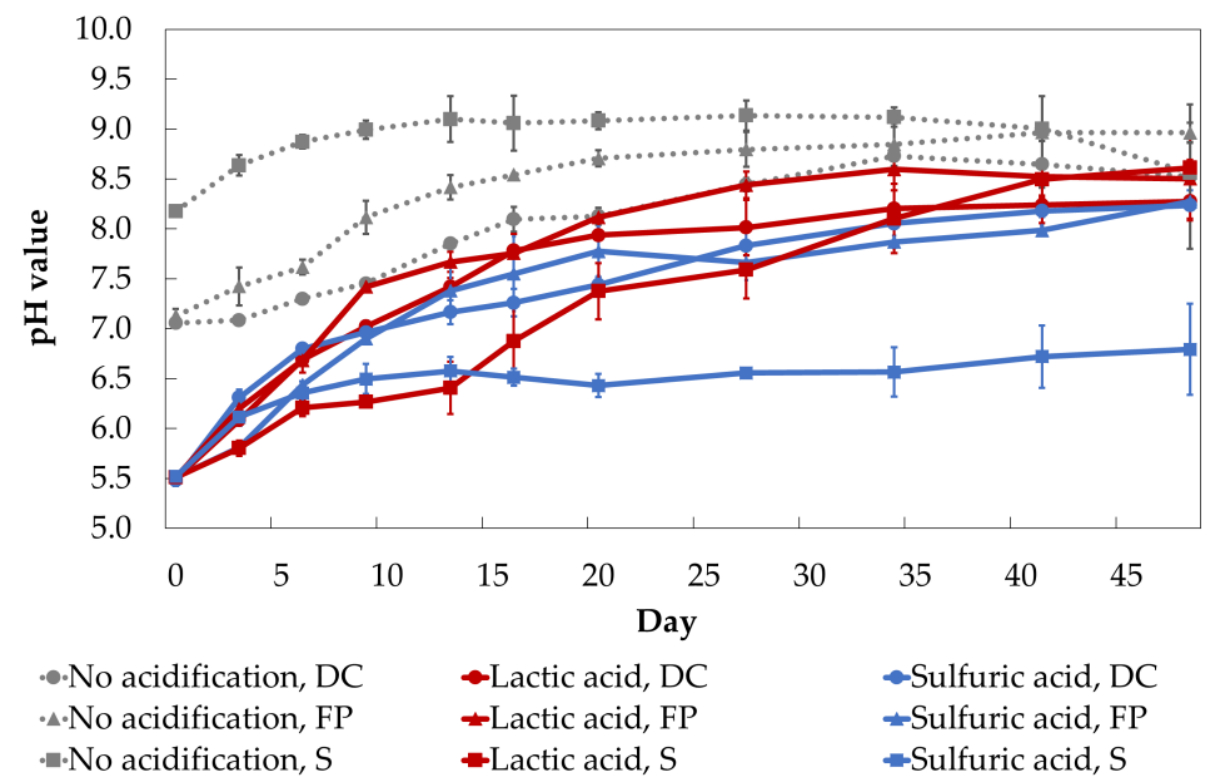

Figure 1. The $\mathrm{pH}$ value of dairy cow $(\mathrm{DC}, \bullet)$, fattening pig $(\mathrm{FP}, \mathbf{\Delta})$, and sow $(\mathrm{S}, \mathbf{\square})$ slurry and after acidification with lactic or sulfuric acid to a $\mathrm{pH}$ value of 5.5 during the storage period of 48 days (means $\pm \mathrm{SD}, n=3$ ).

\subsubsection{Acidification of All Slurries with Sulfuric and Lactic Acid}

After acidification, the $\mathrm{pH}$ value rose again in acidified slurry for both lactic and sulfuric acid (Figure 1 and Table S1). In the long term, only sow slurry acidified by sulfuric acid could achieve a significant $\mathrm{pH}$ value reduction ( $\mathrm{pH} 6.79$ on day 48). In the first days after acidification, the $\mathrm{pH}$ increase was slower in the dairy cow (until day 6) and sow slurry (until day 13) which have been acidified by lactic acid as compared with the use of sulfuric acid. Long-term acidification was more effective by using sulfuric acid in all types of slurry.

\subsubsection{Acidification of Dairy Cow Slurry with Various Organic and Mineral Acids}

The $\mathrm{pH}$ value increased to 8.25 after 48 days, regardless of the type of acid $(p>0.05)$ (Figure 2 and Table S2). In the first six days after acidification to a $\mathrm{pH}$ value of 5.5, the $\mathrm{pH}$ increase was about $0.17 \mathrm{pH}$ units $\mathrm{d}^{-1}$. 


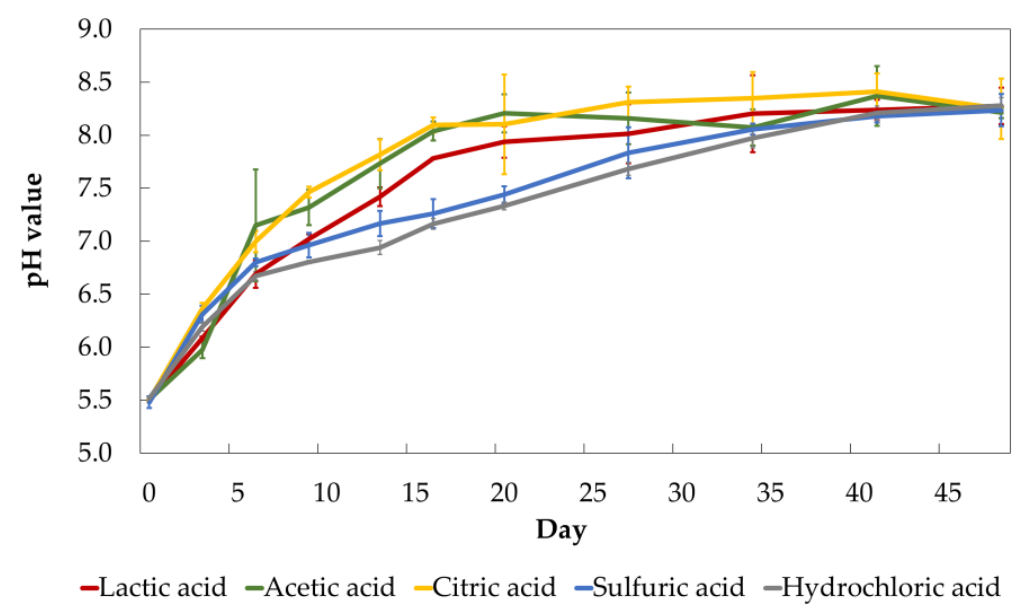

Figure 2. The $\mathrm{pH}$ value of dairy cow slurry after acidification with different organic (lactic, acetic, and citric acid) and mineral acids (sulfuric and hydrochloric acid) to a $\mathrm{pH}$ value of 5.5 during the storage period of 48 days (means $\pm \mathrm{SD}, n=3$ ).

The organic acids led to a strong $\mathrm{pH}$ increase in the first half of the storage period (acetic acid > citric acid > lactic acid). Then, the $\mathrm{pH}$ value tended to stagnate in the second half (from day 20). Acidification with mineral acids resulted in an equally fast $\mathrm{pH}$ increase as with organic acids at the beginning of storage. However, from the second week, the $\mathrm{pH}$ increase was much slower. With sulfuric acid, the $\mathrm{pH}$ value rose slightly faster than with hydrochloric acid.

\subsection{Storage under Anaerobic Conditions}

The storing conditions (aerobic or anaerobic) of the acidified dairy cow slurry had a significant effect on the $\mathrm{pH}$ value during the storage period (Figure 3 and Table S3). The $\mathrm{pH}$ value was $1.9 \mathrm{pH}$ units lower as compared with aerobic storing conditions at the end of the storage period. This effect was observed for both lactic and sulfuric acid. In addition, the $\mathrm{pH}$ value increased slower under anaerobic storing conditions.

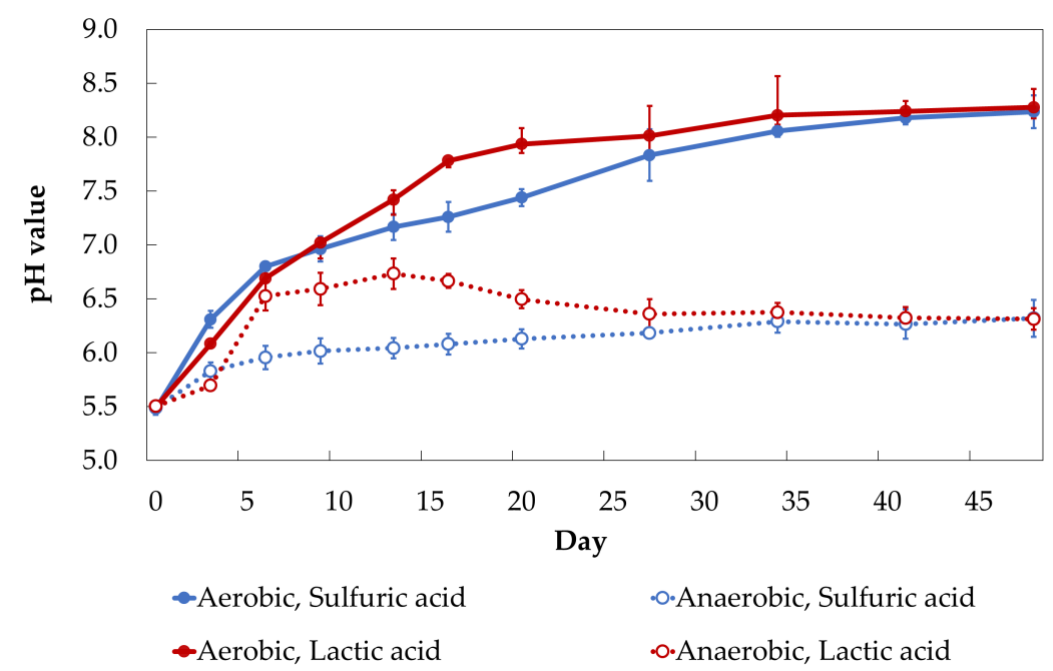

Figure 3. The $\mathrm{pH}$ value of dairy cow slurry after acidification with sulfuric or lactic acid to $\mathrm{pH} 5.5 \mathrm{under}$ aerobic or anaerobic storing conditions during the storage period of 48 days (means $\pm \mathrm{SD}, n=3$ ).

\subsection{Combination of Acid and Glucose}

Initially, the $\mathrm{pH}$ value was lower when glucose ( 0.01 mol glucose $\mathrm{kg}^{-1}$ slurry) in combination with sulfuric acid was added as compared with the acidification by using only sulfuric acid (days 3 and 6) (Figure 4 and Table S4). Therefore, the addition of glucose had a 
significant effect on the $\mathrm{pH}$ value during the first two measurement days after acidification (two-way ANOVA, $p<0.05$ ). However, the addition of glucose resulted in higher $\mathrm{pH}$ values for sow slurry from day 9 and fattening pig slurry from day 16 as compared with the slurry in which exclusively sulfuric acid was added. All in all, the addition of glucose at this dosage in combination with sulfuric acid to the slurry had no significant effect on a better long-term stability of the $\mathrm{pH}$ value of 5.5 as compared with the addition of sulfuric acid alone.

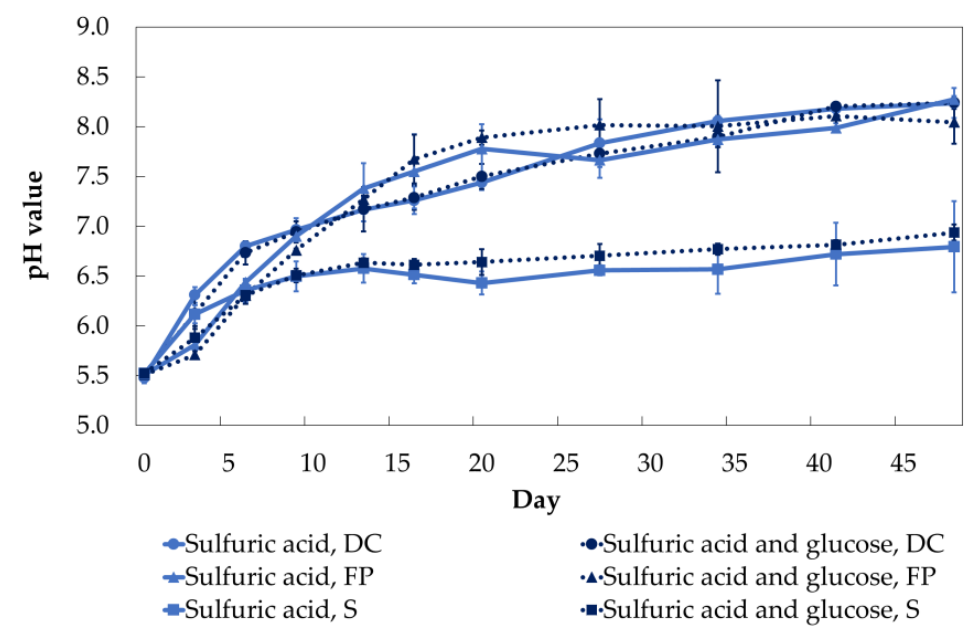

Figure 4. The $\mathrm{pH}$ value of dairy cow $(\mathrm{DC}, \bullet)$, fattening pig $(\mathrm{FP}, \boldsymbol{\Delta})$, and sow $(\mathrm{S}, \mathbf{\square})$ slurry after acidification with sulfuric acid or in combination with glucose addition ( 0.01 mol glucose $\mathrm{kg}^{-1}$ slurry) to a $\mathrm{pH}$ value of 5.5 during the storage period of 48 days (means $\pm \mathrm{SD}, n=3$ ).

\subsection{Separation before Acidification}

The separation process reduced the dry matter content (fattening pig $8.3 \%$ to $1.3 \%$; dairy cow $9.5 \%$ to $3.2 \%$ ). In the first days after acidification, the $\mathrm{pH}$ value of the separated slurry hardly rose (fattening pig) or rose less (dairy cow) as compared with the raw slurry (Figure 5 and Table S5). In the second phase of storage (from day 9 or day 6), the $\mathrm{pH}$ value increased strongly and rapidly, but then remained relatively constant at around 8.6 until the end of storage. The raw slurries had a significantly slower $\mathrm{pH}$ increase. At the end of the storage period (day 48), the $\mathrm{pH}$ values of the acidified raw slurries were lower (8.27 and 8.24) than those of the acidified separated slurries (8.42 and 8.69).

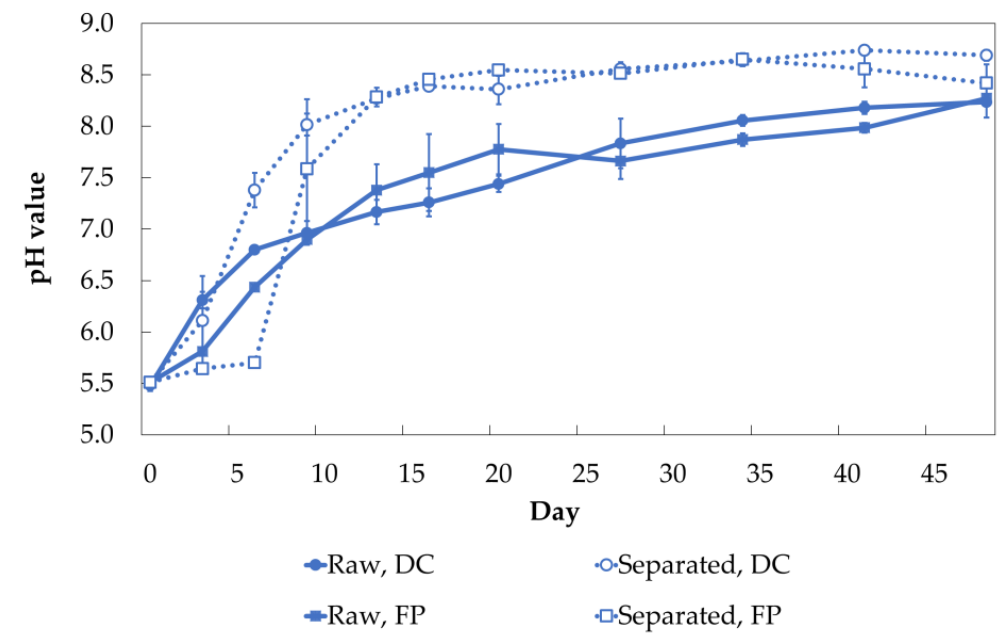

Figure 5. The $\mathrm{pH}$ value of dairy cow $(\mathrm{DC}, \bullet)$ and fattening slurry (FP, $\mathbf{\Delta})$ (raw and separated slurry) after acidification with sulfuric acid to a $\mathrm{pH}$ value of 5.5 during the storage period of 48 days (means $\pm \mathrm{SD}, n=3$ ). 


\subsection{Different Target $p H$ Values}

Lowering the $\mathrm{pH}$ value to 4.5 resulted in a half as strong $\mathrm{pH}$ increase as compared with the acidified slurry to $\mathrm{pH} 5.5$ by day $9(+0.7$ and $+1.5 \mathrm{pH}$ units, respectively). After 48 days, the difference between these two variants was $0.9 \mathrm{pH}$ units, which approximately equals the initial difference in acidification (Figure 6 and Table S6). Acidification of the dairy cow slurry to $\mathrm{pH} 3.0$ resulted in a permanently low $\mathrm{pH}$ value during the entire storage period. Nevertheless, the $\mathrm{pH}$ value also increased from a $\mathrm{pH}$ value from 3.0 to 3.3 in the first three days.

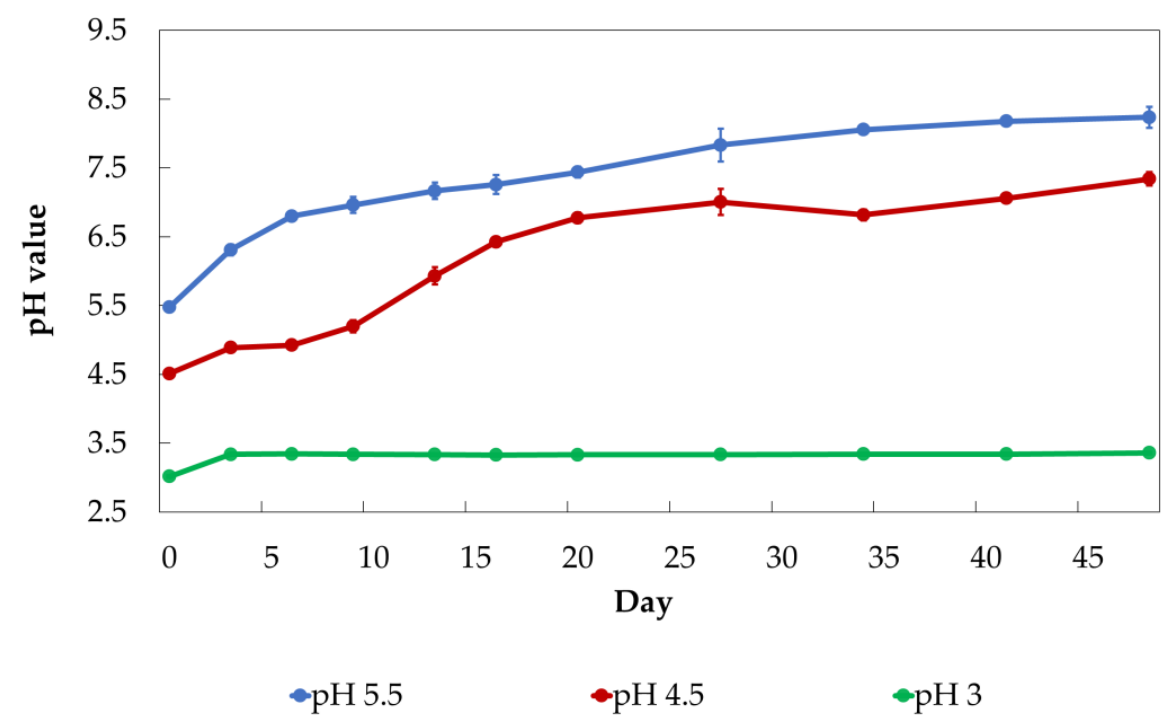

Figure 6. The $\mathrm{pH}$ value of dairy cow slurry after acidification with sulfuric acid to $\mathrm{pH}$ values of 5.5, 4.5 , and 3.0 during the storage period of 48 days (means $\pm \mathrm{SD}, n=3$ ).

\section{Discussion}

\subsection{Amount of Acid}

The amount of acid required to reach the target $\mathrm{pH}$ value is strongly dependent on the different buffer capacities of the slurries. These can be described as a dynamic system because they are able to interact with each other [38,39]. The buffer capacities and their interaction are generally influenced, for example, by the ingredients of the slurry as well as by the temperature and time of storage [38].

In our investigation, the buffer capacity was approximately the same between the dairy cow and fattening pig slurry, because the same amount of acid was used. However, more than three times the amount of acid was required for sow slurry. This could be explained by several factors such as a high initial $\mathrm{pH}$ value or a low VFA content. Furthermore, carbonate is released during the decomposition of urea to ammonia [40]. Therefore, the high $\mathrm{NH}_{4}-\mathrm{N}$ content of the sow slurry (Table 2) also indicates a high carbonate content as compared with the other slurries. Since the carbonate buffer accounts for the largest share of the total buffering capacity of the slurry as compared with the VFA- and $\mathrm{NH}_{3}$-buffer [41], the high carbonate content in the sow slurry could also explain the large amount of acid needed to reach the $\mathrm{pH}$ value of 5.5 .

Joubin [28] required for the acidification of fattening pig slurry to a $\mathrm{pH}$ value of 6.0 the same amount of acid equivalents of lactic, sulfuric and acetic acid, while the cattle slurry needed more lactic acid than sulfuric and acetic acid. In our investigation, however, the acid equivalents in the acidification of cattle slurry differed significantly (Table 3). Regueiro et al. [26] used more sulfuric and lactic acid as compared with acetic acid for acidification to a $\mathrm{pH}$ value of 5.5 . We could not completely confirm this. In our investigation, the least $\mathrm{H}^{+}$equivalents were used for acidification with lactic acid. The lactic acid has the lowest acid dissociation constant (pKa 3.13) of the organic acids, which influences the 
acidification process to a $\mathrm{pH}$ value of 5.5. Therefore, a lower amount of acid was required to achieve the target $\mathrm{pH}$ value because of the higher degree of acidity. The amount of acid depended on the buffer capacity of the slurry and also on the acid characteristic, as was also reported in [26].

The organic matter of slurry can be considered to be a cation exchanger [42]. Cations such as calcium $\left(\mathrm{Ca}^{2+}\right)$ or magnesium $\left(\mathrm{Mg}^{2+}\right)$ can be exchanged by protons. As a consequence, more acid is required to lower the $\mathrm{pH}$ value. This is why we were able to show in our study that the amount of acid can be reduced by a prior separation process, which was in agreement with the study of Fangueiro et al. [43]. This is also in line with Sommer and Husted [44] who reported from a residual alkalinity that is defined as a solid material from organic and inorganic origin. These solids can be removed by the separation process, resulting in a reduction of the buffer capacity in the liquid phase of the slurry. However, Joubin [28] observed that in dairy cow and fattening pig slurry more acid for the first acidification to $\mathrm{pH} 5.5$ was needed in filtrated as compared with raw slurry. Furthermore, it was mentioned that the total amount of acid including re-acidifications used during a storage period of two months was higher in the filtrated slurry. Other factors than only the dry residue may have been affected by the filtration. These may have influenced the buffer capacity [28].

When considering the amount of acid in our study (Table 3), it is important to note that dilute acids were used in order to improve the accuracy of the measurement parameters during the titration. In practice, much higher concentrated acids are usually used [14,15], which has the advantage of reducing storage capacity.

\section{2. $p H$ Value during Storage}

Long-term $\mathrm{pH}$ reduction could only be observed if slurry is acidified to $\mathrm{pH} 3.0$ (Figure 6). Apart from that, the $\mathrm{pH}$ value of all treatments in our investigation increased again during the storage period of 48 days. The $\mathrm{pH}$ increase in acidified and non-acidified slurry may be attributed to the mineralization of organic nitrogen and the degradation of organic acids which caused an increased bicarbonate concentration [26,36-38,45,46]. However, acidification affects the buffer capacity of the slurry leading, for example, to a reduction in the carbonate buffer of the acidified slurry due to the release of gaseous carbon dioxide [10].

Regueiro et al. [26] observed a strong increase in $\mathrm{pH}$ value after acidification within the first 20 days. In our investigation, the $\mathrm{pH}$ increase was also highest during this period (Figures 1-5). Other authors have also observed a continuous $\mathrm{pH}$ increase of acidified pig slurry (with sulfuric acid), independent of storage temperature [25]. Joubin [28] reported a $\mathrm{pH}$ increase within the first 10 days after acidification from a $\mathrm{pH}$ of 6.0 to a $\mathrm{pH}$ of 7.0 and 6.7 for cattle and pig slurry, respectively. In this mentioned study, sulfuric acid had a slightly better effectiveness as compared with lactic and acetic acid [28]. The organic acids also resulted in a faster $\mathrm{pH}$ increase in our investigation (Figure 2), which also agrees with [26]. The decomposition of the organic acids used for acidification increased the formation of the carbonate buffer, resulting in a faster $\mathrm{pH}$ increase than could be observed during acidification with mineral acids.

In the group of the investigated organic acids, the amount of acid required to acidify the slurry was lowest in the lactic acid, which had the advantage that less (alkaline) carbonate was formed as compared with all other organic acids. This had a positive effect on the long-term stability of the $\mathrm{pH}$ value, as a strong increase in the $\mathrm{pH}$ value was avoided (Figure 2). In addition, the part of lactic acid which was not yet degraded had a stronger effect than the other organic acids due to its lower pKa value (Table 1).

The temperature during storage influences the progress of biodegradation processes, and thus also the $\mathrm{pH}$ value increase. The authors of [15] and [38] observed a faster $\mathrm{pH}$ increase during warm storage than during cold storage. This effect could not be considered in our investigation due to capacity constraints, therefore the storage was only carried out at laboratory temperature (approximately $22^{\circ} \mathrm{C}$ ). 
In the study by Eriksen et al. [27] laboratory acidification of both fresh ( $\mathrm{pH} 4.5)$ and aged cattle slurry ( $\mathrm{pH} 4.9$ ) with hydrochloric acid resulted in a $\mathrm{pH}$ increase to about 6.4 after 90 days. An increase of $0.9 \mathrm{pH}$ units during storage was also observed for freshly acidified slurry on farms ( $\mathrm{pH}$ 5.6) [27]. In our investigation, the slurry was at least one week old. Possibly, the $\mathrm{pH}$ increase caused by the degradation of volatile fatty acids and the formation of the carbonate buffer in the first weeks after excretion [38] led to an even stronger $\mathrm{pH}$ increase after the acidification had been conducted. Other authors have also suggested that the degradation of dissociated organic acids was responsible for the $\mathrm{pH}$ increase after acidification $[26,45,46]$. The more organic matter the slurry contains, which can also be seen in the dry residue content (Table 2), the more VFA can be formed [38,42]. These, in turn, increase the $\mathrm{pH}$ value again through the transformation to carbonate, and therefore the acid effect is overcome. The carbonate degasses as carbon dioxide [42,47], which reduces the buffer capacity [38]. In our investigated sow slurry, there was hardly any organic matter and VFA, therefore, there was a low carbonate formation. This could be the reason why the $\mathrm{pH}$ value of the slurry acidified with sulfuric acid remained relatively and constantly low, since, on the one hand, the acid effect of the sulfuric acid was not overcome by the buffers formed during storage (Figure 1). The lactic acid, on the other hand, was degraded, which could thus lead to an increase in the $\mathrm{pH}$ value of sow slurry.

In the anaerobic storage of acidified slurry, a relatively strong $\mathrm{pH}$ increase was observed only in the first days after acidification. This could be due to the degradation of VFA, which has also occurred in anaerobic conditions. Thereafter, a constantly low $\mathrm{pH}$ value was observed during anaerobic storage. This coincided with the authors of [39], who observed a slightly higher $\mathrm{pH}$ increase in aerated acidified slurry for both pig and cattle slurry as compared with non-aerated acidified slurry. In a study by Berg [16], the acidification of pig slurry with lactic acid and additional covering with perlite reduced $\mathrm{NH}_{3}$ and partly also $\mathrm{CH}_{4}$ emissions during storage more than in the case if only acidification was carried out without covering. Kupper et al. [5] reported that covering non-acidified slurry with permeable synthetic or natural floating covers could lead to an increase in methane emissions. However, since acidification prevents the formation of methane in the slurry, acidified slurry can be stored anaerobically without problems. Thus, in addition to ammonia emissions, methane emissions can also be reduced by a combination of acidification and covering of the slurry. Berg et al. [21] showed that there was a reduction of the $\mathrm{pH}$ value to below 5.5 in the first two weeks when the perlites were mixed with lactic acid. A mixture of straw and lactic acid was not as effective [21]. Contact with oxygen on the surface of the slurry can accelerate the conversion processes. This leads to the degradation of organic matter so that more carbonate is available to form the carbonic acid-bicarbonate buffer, which in turn leads to an increase in the $\mathrm{pH}$ value [38]. In our investigation, a similar effect was observed in aerobically stored slurry as compared with anaerobically stored slurry, as the $\mathrm{pH}$ value increased faster in aerobically storage conditions (Figure 3).

The sample bottles we used in our investigation were relatively small, therefore, the atmospheric oxygen when stored aerobically was able to diffuse through the entire slurry. In this case, our investigation shows the $\mathrm{pH}$ value and conversion processes at the surface level of the slurry in commercial storage tanks. Ammonia emissions also occur in this layer [48]. Sample bottles that were stored anaerobically provide information about these processes at deeper levels or if the surface is covered. Furthermore, it is noticeable that the $\mathrm{pH}$ value of the samples acidified with lactic and sulfuric acid was the same after 48 days of storage under anaerobic conditions ( $\mathrm{pH}$ value 6.3). This indicates that organic and mineral acids have the same effect on the $\mathrm{pH}$ value during long-term anaerobic storage of slurry. In the case of anaerobic storage, organic acids could therefore also lead to a good low $\mathrm{pH}$ stability after a one-time acidification process.

Misselbrook et al. [15] reported that the $\mathrm{pH}$ value, which was measured $10 \mathrm{~cm}$ below the surface, was between 0 and $0.1 \mathrm{pH}$ units lower than at the surface of cattle slurry. Berg et al. [1] found only slight differences between the $\mathrm{pH}$ value at the surface and in the sediment, especially in acidified slurry. We stirred the samples before each measure- 
ment, and therefore we could not consider the $\mathrm{pH}$ value in different layers. However, Hörnig et al. [49] also observed an increase in $\mathrm{pH}$ value because of complete homogenization of the samples in the case of acidified slurry at $\mathrm{pH}$ values of 4.3 and 4.8 , whereas they found no effect for the samples acidified to $\mathrm{pH} 3.8$ [49]. Possibly, the $\mathrm{pH}$ value is then already so low that no more biological conversion processes can take place, and therefore these processes cannot be affected by the atmospheric oxygen (Figure 6).

The authors of [20] and [21] observed that the coverage of the slurry with straw or perlite and addition of saccharose resulted in a significantly lower $\mathrm{pH}$ value than the coverage of slurry alone (without additives) after several months of storage. Studies have also shown that the addition of lactic acid instead of saccharose led to an even better $\mathrm{pH}$ value reduction [20,21]. Clemens et al. [34] were also able to achieve a reduction of the $\mathrm{pH}$ value below 5.5 by adding $0.1 \mathrm{~mol}$ glucose $\mathrm{L}^{-1}$ slurry. In our investigation, the addition of glucose (besides sulfuric acid) to the slurry resulted in a lower $\mathrm{pH}$ value in the first week as compared with acidification alone. The glucose was probably degraded to VFA (first week after acidification), which resulted, similar to the addition of organic acids, in a decrease in the $\mathrm{pH}$ value, which compensated for the general $\mathrm{pH}$ increase. Immediately after degradation of the VFA and the resulting strengthening of the carbonate buffer, the $\mathrm{pH}$ value consequently increased more than it had been observed for the acid-only variant (second week after acidification). This effect was especially noticeable for acidified sow slurry. In another study, however, a permanent $\mathrm{pH}$ reduction to $\mathrm{pH} 4.0$ due to the addition of sugar ( 0.5 mol glucose $\mathrm{L}^{-1}$ slurry) in co-fermented mixed slurry was found even after 40 days of storage. This might be caused by the lower buffer capacity [50] and the higher glucose addition as compared with our investigation. In addition, in our investigated sow slurry, only a small buffer capacity could be provided by the decomposition of the organic matter.

Fangueiro et al. [51] did not observe an increase in $\mathrm{pH}$ value during the storage period of 22 days, neither in high-fiber nor in separated cattle slurry. In their study parts of the slurry were acidified to 5.5 with sulfuric acid. Again, there was no change in $\mathrm{pH}$ value at the end of the storage period [51]. Hörnig et al. [49] also found no effect on the $\mathrm{pH}$ value during storage due to a difference of $2.6 \%$ in dry residue content in acidified dairy cow slurry. The separated slurry contained hardly any organic substances that could be degraded quickly. Therefore, in our investigation, the $\mathrm{pH}$ increase was lower than in the raw slurry in the first week after acidification. As the separated slurry had a much lower buffer capacity (lower amount of acid to adjust the $\mathrm{pH}$ value 5.5, see Section 3.1), even a small degradation of the organic matter led to a strong $\mathrm{pH}$ increase from the first week. In addition, a smaller amount of acid was required for the acidification of separated slurry than in raw slurry. Therefore, the acid could be neutralized faster in separated slurry. Although separation allows better nutrient export, the solid phase must also be considered to be an emission source [52]. These emissions could be reduced by composting, anaerobic digestion or acidification [53-55].

Hörnig et al. [49] reported a constant $\mathrm{pH}$ value when acidifying dairy cow slurry with lactic or nitric acid to around a $\mathrm{pH}$ value of 4.0 as compared with target $\mathrm{pH}$ values of 4.5 and 5.0. Another study showed that even when acidifying dairy cow and pig slurry with different acids to $\mathrm{pH}$ value 3.5 , the $\mathrm{pH}$ value could not remain constantly low. The greatest $\mathrm{pH}$ increase was between 15 and 20 days after acidification [26]. Whereas in our investigation, the greatest $\mathrm{pH}$ increase in this period was in the slurry acidified to a $\mathrm{pH}$ value of 4.5. Berg et al. [1] acidified cattle slurry with lactic acid to different $\mathrm{pH}$ values $(3.8,4.3$, and 4.8$)$; only acidification to a $\mathrm{pH}$ value of 3.8 resulted in a steady low $\mathrm{pH}$ value over 150 days, whereas the other two variants had to be post-acidified at irregular intervals (first post-acidification after 63 days) [1]. In addition, this study showed that a strong initial acidification of the slurry ( $\mathrm{pH}$ 3.8) as it was shown in our investigation ( $\mathrm{pH}$ 3.0), leads to a steady low $\mathrm{pH}$ value. Nevertheless, in our investigation, a relatively strong $\mathrm{pH}$ increase was observed ( +0.3 and $+0.4 \mathrm{pH}$ units, respectively) in both $\mathrm{pH} 3.0$ and 4.5 acidified slurry during the first three days after acidification. It suggests that the $\mathrm{pH}$ 
increase is not biological but partly caused by chemical reactions. This might be explained by carbonates in the slurry, which dissolve slowly after the acidification and partially neutralize the acidifying effect of sulfuric acid.

However, acidification to a $\mathrm{pH}$ value of 3.0 does not seem practical because a low $\mathrm{pH}$ value leads to a decrease in the growth or loss of yields [56,57]. Furthermore, a large amount of acid is necessary to reduce the $\mathrm{pH}$ value. This would increase the cost of acid and the need for lime to maintain soil $\mathrm{pH}$ value.

The fact that after acidification to a $\mathrm{pH}$ value of 5.5 a constantly low $\mathrm{pH}$ value could not be observed, allows the conclusion to be drawn that although $\mathrm{NH}_{3}$ emissions are reduced, the microbiological conversion processes are not yet inhibited at this $\mathrm{pH}$ value.

\section{Conclusions}

Microbial degradation of organic matter in the slurry results in the formation of carbonate and ammonium and thus to an increase in $\mathrm{pH}$ value. Acidification of the slurry to a $\mathrm{pH}$ value of 5.5 prevents the release of ammonia and the formation of methane, but does not completely prevent the decomposition of organic matter. This is only possible at $\mathrm{pH}$ values below 4 . Thus, even with acidified slurry, the $\mathrm{pH}$ inevitably rises again over time. Under aerobic conditions, the decomposition of organic matter, and thus the $\mathrm{pH}$ increase occurs very quickly. Under anaerobic conditions, it is considerably delayed. Separated slurry contains less organic matter. Therefore, separated slurry requires a smaller amount of acid for acidification than raw slurry. Since, in separated slurry, less organic matter could be degraded, the $\mathrm{pH}$ increase is delayed as compared with raw slurry. However, a degradation of the still slightly available organic matter and the reduced buffer capacity leads to a stronger $\mathrm{pH}$ increase. Therefore, prolonged storage of the separated acidified slurry is not recommended.

In principle, any acid is suitable for acidifying slurry to a $\mathrm{pH}$ value of 5.5. Even the organic acids, which are formed by the decomposition of easily degradable organic compounds, are able to do this. However, the organic acids themselves are degraded during storage. This is the reason why the $\mathrm{pH}$ value increases faster than in the case of slurry acidified with mineral acids. After only three days, the $\mathrm{pH}$ value may have risen again to such an extent that efficient mitigation of methane formation and ammonia release is no longer possible.

Low temperatures or anaerobic conditions during storage can considerably delay the degradation of the organic matter. This can improve the efficiency of acidification especially with organic acids.

Although it has been shown that there are appropriate alternative acids to sulfuric acid, it still seems to be the best in regard to the required amount and costs of acid. However, to avoid sulfur over fertilization to soils, the combination of organic acids and anaerobic storage represents a useful alternative for acidification of slurry.

One-time acidification of slurry is suitable to lower the $\mathrm{pH}$ value of slurry just before field application, and therefore ammonia emissions are reduced during application. It is not suitable for permanently reducing methane formation and ammonia emissions in the barn or in storage tanks due to the increase in $\mathrm{pH}$ value. This would need repeated or continuous acidification.

Supplementary Materials: The following are available online at https:/ / www.mdpi.com/article/10 .3390 /agronomy11071319/s1, Table S1: The $\mathrm{pH}$ value of dairy cow, fattening pig, and sow slurry, and $\mathrm{pH}$ value after acidification with lactic or sulfuric acid during storage period of 48 days (means $\pm \mathrm{SD}$, $n=3)$, Table S2: The $\mathrm{pH}$ value of dairy cow slurry after acidification with different organic or mineral acids during storage period of 48 days (means $\pm \mathrm{SD}, n=3$ ), Table S3: The $\mathrm{pH}$ value of dairy cow slurry after acidification with sulfuric or lactic acid under aerobic or anaerobic storing conditions during storage period of 48 days (means $\pm \mathrm{SD}, n=3$ ), Table S4: The $\mathrm{pH}$ value of dairy cow, fattening pig, and sow slurry after acidification with sulfuric acid or in combination with glucose addition ( $0.01 \mathrm{~mol}$ glucose $\mathrm{kg}^{-1}$ slurry) during storage period of 48 days (means $\pm \mathrm{SD}, n=3$ ), Table S5: The $\mathrm{pH}$ value of dairy cow and fattening slurry (raw and separated slurry) after acidification with sulfuric 
acid during storage period of 48 days (means $\pm \mathrm{SD}, n=3$ ), Table S6: The $\mathrm{pH}$ value of dairy cow slurry after acidification with sulfuric acid to $\mathrm{pH}$ values of 5.5, 4.5, and 3 during a storage period of 48 days (means $\pm \mathrm{SD}, n=3$ ).

Author Contributions: Conceptualization, V.O., A.K., J.C., W.B. and M.T.; methodology, V.O., A.K. and M.T.; software, V.O. and A.K.; validation, V.O., A.K. and M.T.; formal analysis, V.O., A.K. and M.T.; investigation, V.O. and A.K.; resources, W.B. and M.T.; data curation, V.O., A.K., J.C. and M.T.; writing —original draft preparation, V.O. and A.K.; writing—review and editing, J.C., W.B. and M.T.; visualization, V.O. and A.K.; supervision, M.T.; project administration, J.C. and W.B.; funding acquisition, J.C., W.B. and M.T. All authors have read and agreed to the submitted version of the manuscript.

Funding: This research is supported by the Federal Ministry of Food and Agriculture (BMEL) based on a decision of the Parliament of the Federal Republic of Germany via the Federal Office for Agriculture and Food (BLE) under the innovation support program, grant number 281B102316. This work was supported by the Open Access Publication Fund of the University of Bonn.

Data Availability Statement: The data presented in this study are available in Supplementary Material Table S1-S6.

Acknowledgments: The authors thank the three farmers for their support.

Conflicts of Interest: The authors declare no conflict of interest. The funders had no role in the design of the study; in the collection, analyses, or interpretation of data; in the writing of the manuscript, or in the decision to publish the results.

\section{References}

1. Berg, W.; Türk, M.; Hellebrankd, H.J. Effects of acidifying liquid cattle manure with nitric or lactic acid on gaseous emissions. In Proceedings of the Workshop on Agricultural Air Quality, Potomac, MD, USA, 5-8 June 2006; pp. $492-498$.

2. Ti, C.; Xia, L.; Chang, S.X.; Yan, X. Potential for mitigating global agricultural ammonia emission: A meta-analysis. Environ. Pollut. 2019, 245, 141-148. [CrossRef]

3. IPCC. Climate Change and Land: An IPCC Special Report on Climate Change, Desertification, Land Degradation, Sustainable Land Management, Food Security, and Greenhouse Gas Fluxes in Terrestrial Ecosystems. 2019. Available online: https: //www.ipcc.ch/site/assets/uploads/2019/08/4.-SPM_Approved_Microsite_FINAL.pdf (accessed on 23 June 2021).

4. IPCC. Global Warming of $1.5^{\circ} \mathrm{C}$. An IPCC Special Report on the Impacts of Global Warming of $1.5^{\circ} \mathrm{C}$ above Pre-Industrial Levels and Related Global Greenhouse Gas Emission Pathways, in the Context of Strengthening the Global Response to the Threat of Climate Change, Sustainable Development, and Efforts to Eradicate Poverty. 2018. Available online: https: //www.ipcc.ch/site/assets/uploads/sites/2/2019/06/SR15_Full_Report_High_Res.pdf (accessed on 23 June 2021).

5. Kupper, T.; Häni, C.; Neftel, A.; Kincaid, C.; Bühler, M.; Amon, B.; Vanderzaag, A. Ammonia and greenhouse gas emissions from slurry storage-A review. Agric. Ecosyst. Envrion. 2020, 300, 106963. [CrossRef]

6. Amon, B.; Kryvoruchko, V.; Amon, T.; Zechmeister-Boltenstern, S. Methane, nitrous oxide and ammonia emissions during storage and after application of dairy cattle slurry and influence of slurry treatment. Agric. Ecosyst. Envrion. 2006, 112, 153-162. [CrossRef]

7. Erisman, J.W.; Bleeker, A.; Hensen, A.; Vermeulen, A. Agricultural air quality in Europe and the future perspectives. Atmos. Environ. 2008, 42, 3209-3217. [CrossRef]

8. Krupa, S. Effects of atmospheric ammonia (NH3) on terrestrial vegetation: A review. Environ. Pollut. 2003, 124, 179-221. [CrossRef]

9. Arogo, J.; Westerman, P.W.; Heber, A.J.; Robarge, W.P.; Classen, J.J. Ammonia emissions from animal feeding operations. In Animal Agriculture and the Environment, National Center for Manure E Animal Waste Management White Papers; Rice, J.M., Caldwell, D.F., Humenik, F.J., Eds.; ASABE: St. Joseph, MI, USA, 2006; pp. 41-48.

10. Fangueiro, D.; Hjorth, M.; Gioelli, F. Acidification of animal slurry-A review. J. Environ. Manag. 2015, 149, 46-56. [CrossRef]

11. Conn, K.L.; Topp, E.; Lazarovits, G. Factors influencing the concentration of volatile fatty acids, ammonia, and other nutrients in stored liquid pig manure. J. Environ. Qual. 2007, 36, 440-447. [CrossRef]

12. Arogo, J.; Westerman, P.W.; Liang, Z.S. Comparing Ammonium Ion Dissociation Constant in Swine Anaerobic Lagoon Liquid and Deionized Water. Trans. ASAE 2003, 46, 1415-1419. [CrossRef]

13. Wang, K.; Huang, D.; Ying, H.; Luo, H. Effects of acidification during storage on emissions of methane, ammonia, and hydrogen sulfide from digested pig slurry. Biosyst. Eng. 2014, 122, 23-30. [CrossRef]

14. Hjorth, M.; Cocolo, G.; Jonassen, K.; Abildgaard, L.; Sommer, S.G. Continuous in-house acidification affecting animal slurry composition. Biosyst. Eng. 2015, 132, 56-60. [CrossRef]

15. Misselbrook, T.; Hunt, J.; Perazzolo, F.; Provolo, G. Greenhouse gas and ammonia emissions from slurry storage: Impacts of temperature and potential mitigation through covering (pig slurry) or acidification (cattle slurry). J. Environ. Qual. 2016, 45, 1520-1530. [CrossRef] 
16. Berg, W. Emission Abatement through pH value reducing slurry covers. Agric. Eng. 2002, 57, 274-275. [CrossRef]

17. Stevens, R.J.; Laughlin, R.J.; Frost, J.P. Effect of acidification with sulphuric acid on the volatilization of ammonia from cow and pig slurries. J. Agric. Sci. 1989, 113, 389-395. [CrossRef]

18. Nyord, T.; Liu, D.; Eriksen, J.; Adamsen, A. Effect of acidification and soil injection of animal slurry on ammonia and odour emissions. In Proceedings of the 15th RAMIRAN Conference, Versailles, France, 3-5 June 2013.

19. Panetta, D.M.; Powers, W.J.; Lorimor, J.C. Management strategy impacts on ammonia volatilization from swine manure. J. Environ. Qual. 2005, 34, 1119-1130. [CrossRef]

20. Berg, W.; Pazsiczki, I. Mitigation of methane emissions during manure storage. Int. Congr. Ser. 2006, 1293, 213-216. [CrossRef]

21. Berg, W.; Brunsch, R.; Pazsiczki, I. Greenhouse gas emissions from covered slurry compared with uncovered during storage. Agric. Ecosyst. Envrion. 2006, 112, 129-134. [CrossRef]

22. ten Hoeve, M.; Nyord, T.; Peters, G.M.; Hutchings, N.J.; Jensen, L.S.; Bruun, S. A life cycle perspective of slurry acidification strategies under different nitrogen regulations. J. Clean. Prod. 2016, 127, 591-599. [CrossRef]

23. Loide, V.; Saue, T.; Võsa, T.; Tamm, K. The effect of acidified slurry on crop uptake and leaching of nutrients from a loamy topsoil. Acta Agric. Scand. Sect. B Soil Plant Sci. 2020, 70, 31-38. [CrossRef]

24. Vestergaard, A.V. Status, Economy and Consideration by Acidification of Slurry. 2017. Available online: http:/ / balticslurry.eu/ wp-content/uploads/2017/03/SEGES-review-Slurry-acidification.pdf (accessed on 23 June 2021).

25. Eriksen, J.; Sørensen, P.; Elsgaard, L. The fate of sulfate in acidified pig slurry during storage and following application to cropped soil. J. Environ. Qual. 2008, 37, 280-286. [CrossRef]

26. Regueiro, I.; Coutinho, J.; Fangueiro, D. Alternatives to sulfuric acid for slurry acidification: Impact on slurry composition and ammonia emissions during storage. J. Clean. Prod. 2016, 131, 296-307. [CrossRef]

27. Eriksen, J.; Andersen, A.J.; Poulsen, H.V.; Adamsen, A.P.S.; Petersen, S.O. Sulfur turnover and emissions during storage of cattle slurry: Effects of acidification and sulfur addition. J. Environ. Qual. 2012, 41, 1633-1641. [CrossRef] [PubMed]

28. Joubin, M. Animal Slurry Acidification: Effects of Slurry Characteristics, Use of Different Acids, Slurry pH Buffering; RISE Rapport 2018:15; RISE Research Institutes of Sweden: Uppsala, Sweden, 2018. Available online: http://balticslurry.eu/wp-content/ uploads/2018/03/RISE-Rapport-15-2018_web.pdf (accessed on 23 June 2021).

29. Regueiro, I.; Coutinho, J.; Fangueiro, D. Comparison of different approaches for ammonia emissions minimization by acidification of dairy and pig slurries. In Proceedings of the RAMIRAN 2013: 15th International Conference, Versailles, France, 2013; Bacheley, H., Cambier, P., Cheviron, N., Formisano, S., Houot, S., Lepeuple, A.-S., Revallier, A., Vallez, G., Eds.; Verlag nicht Ermittelbar: Versailles, France, 2013; ISBN 9782738013378.

30. Bittman, S.; Dedina, M.; Howard, C.M.; Oenema, O.; Sutton, M.A. Options for Ammonia Mitigation: Guidance from the UNECE Task Force on Reactive Nitrogen; Centre for Ecology \& Hydrology, on behalf of Task Force on Reactive Nitrogen, of the UNECE Convention on Long Range transboundary Air Pollution: Edinburgh, UK, 2014; ISBN 978-1-906698-46-1.

31. Dai, X.R.; Blanes-Vidal, V. Emissions of ammonia, carbon dioxide, and hydrogen sulfide from swine wastewater during and after acidification treatment: Effect of pH, mixing and aeration. J. Environ. Manag. 2013, 115, 147-154. [CrossRef] [PubMed]

32. Sindhöj, E.; Rodhe, L. Examples of Implementing Manure Processing Technology at Farm Level: Knowledge Report; JTI-Swedish Institute of Agricultural and Environmental Engineering: Uppsala, Sweden, 2013. Available online: https://www.ecsab.com/BM_ ManureProcessingReport.pdf (accessed on 23 June 2021).

33. Locher, F.W. Chemischer Angriff auf Beton. In Technisch-Wissenschaftliche Zementtagung; Verein Deutscher Zementwerke: München, Germany, 1966.

34. Clemens, J.; Bergmann, S.; Vandré, R. Reduced ammonia emissions from slurry after self-acidification with organic supplements. Environ. Technol. 2002, 23, 429-435. [CrossRef] [PubMed]

35. Bastami, M.; Jones, D.; Chadwick, D. Mitigating greenhouse gas and ammonia emissions from stored slurry through the addition of brewing sugar and a biological additive. BJECC 2016, 6, 236-249. [CrossRef]

36. Husted, S.; Jensen, L.S.; Jørgensen, S.S. Reducing ammonia loss from cattle slurry by the use of acidifying additives: The role of the buffer system. J. Sci. Food Agric. 1991, 57, 335-349. [CrossRef]

37. Sommer, S.G.; Husted, S. A simple model of pH in slurry. J. Agric. Sci. 1995, 124, 447-453. [CrossRef]

38. Overmeyer, V.; Holtkamp, F.; Clemens, J.; Büscher, W.; Trimborn, M. Dynamics of different buffer systems in slurries based on time and temperature of storage and their visualization by a new mathematical tool. Animals 2020, 10, 724. [CrossRef]

39. Sørensen, P.; Eriksen, J. Effects of slurry acidification with sulphuric acid combined with aeration on the turnover and plant availability of nitrogen. Agric. Ecosyst. Envrion. 2009, 131, 240-246. [CrossRef]

40. Sigurdarson, J.J.; Svane, S.; Karring, H. The molecular processes of urea hydrolysis in relation to ammonia emissions from agriculture. Rev. Environ. Sci. Biotechnol. 2018, 17, 241-258. [CrossRef]

41. Georgacakis, D.; Sievers, D.M.; Iannotti, E.L. Buffer stability in manure digesters. Agric. Wastes 1982, 4, 427-441. [CrossRef]

42. Christensen, M.L.; Sommer, S.G. Manure characterisation and inorganic chemistry. In Animal Manure: Recycling, Treatment, and Management; Jensen, L.S., Christensen, M.L., Sommer, S.G., Schmidt, T., Eds.; John Wiley \& Sons Inc.: Chichester, UK, 2013; pp. 41-65, ISBN 9781118676677.

43. Fangueiro, D.; Pereira, J.L.; Macedo, S.; Trindade, H.; Vasconcelos, E.; Coutinho, J. Surface application of acidified cattle slurry compared to slurry injection: Impact on $\mathrm{NH}_{3}, \mathrm{~N}_{2} \mathrm{O}, \mathrm{CO}_{2}$ and $\mathrm{CH}_{4}$ emissions and crop uptake. Geoderma 2017, 306, 160-166. [CrossRef] 
44. Sommer, S.G.; Husted, S. The chemical buffer system in raw and digested animal slurry. J. Agric. Sci. 1995, 124, 45-53. [CrossRef]

45. Kai, P.; Pedersen, P.; Jensen, J.E.; Hansen, M.N.; Sommer, S.G. A whole-farm assessment of the efficacy of slurry acidification in reducing ammonia emissions. Eur. J. Agron. 2008, 28, 148-154. [CrossRef]

46. Petersen, S.O.; Andersen, A.J.; Eriksen, J. Effects of cattle slurry acidification on ammonia and methane evolution during storage. J. Environ. Qual. 2012, 41, 88-94. [CrossRef]

47. Møller, H.B.; Sommer, S.G.; Ahring, B.K. Separation efficiency and particle size distribution in relation to manure type and storage conditions. Bioresou. Technol. 2002, 85, 189-196. [CrossRef]

48. Ni, J. Mechanistic Models of Ammonia Release from Liquid Manure: A Review. J. Agric. Eng. Res. 1999, 72, 1-17. [CrossRef]

49. Hörnig, G.; Berg, W.; Türk, M. Emissionsminderung durch Ansäuern von Gülle. Agric. Eng. 1998, 53, 146-147. [CrossRef]

50. Clemens, J.; Wulf, S. Reduktion der Ammoniakausgasung aus Kofermentationssubstraten und Gülle während der Lagerung und Ausbringung durch interne Versaurung mit in NRW anfallenden organischen Kohlenstofffraktionen, Forschungsbericht Nr. 121; Lehr-und Forschungsschwerpunkt "Umweltverträgliche und Standortgerechte Landwirtschaft", Landwirtschaftliche Fakultät der Rheinischen Friedrich Wilhelms-Universität Bonn, Eds.; Lehr-und Forschungsschwerpunkt: Bonn, Germany, 2005. Available online: https://bonndoc.ulb.uni-bonn.de/xmlui/bitstream/handle/20.500.11811/1215/USL_Forschungsbericht_12 1.pdf? sequence $=1 \&$ is Allowed $=\mathrm{y}$ (accessed on 23 June 2021).

51. Fangueiro, D.; Surgy, S.; Coutinho, J.; Vasconcelos, E. Impact of cattle slurry acidification on carbon and nitrogen dynamics during storage and after soil incorporation. J. Plant Nutr. Soil Sci. 2013, 176, 540-550. [CrossRef]

52. Dinuccio, E.; Berg, W.; Balsari, P. Gaseous emissions from the storage of untreated slurries and the fractions obtained after mechanical separation. Atmos. Environ. 2008, 42, 2448-2459. [CrossRef]

53. Sommer, S.G.; Hjorth, M.; Leahy, J.J.; Zhu, K.; Christel, W.; Sørensen, C.G.; Sutaryo, S. Pig slurry characteristics, nutrient balance and biogas production as affected by separation and acidification. J. Agric. Sci. 2015, 153, 177-191. [CrossRef]

54. Cuhls, C.; Mähl, B.; Clemens, J. Gewitra Ingenieurgesellschaft für Wissenstransfer mbH. In Ermittlung der Emissionssituation bei der Verwertung von Bioabfällen; Umweltbundesamt: Dessau-Roßlau, Germany, 2015. Available online: https://www. umweltbundesamt.de/sites/default/files/medien/378/publikationen/texte_39_2015_ermittlung_der_emissionssituation_ bei_der_verwertung_von_bioabfaellen.pdf (accessed on 23 June 2021).

55. Clemens, J.; Trimborn, M.; Weiland, P.; Amon, B. Mitigation of greenhouse gas emissions by anaerobic digestion of cattle slurry. Agric. Ecosyst. Envrion. 2006, 112, 171-177. [CrossRef]

56. Evans, L.S.; Lewin, K.F.; Santucci, K.A.; Owen, E.M. Yields of field-grown soybeans exposed to simulated acidic deposition. Environ. Pollut. 1989, 61, 47-57. [CrossRef]

57. Choi, E.; Moon, J.; Lee, W.; Son, S.; Lee, S.; Cho, I. The response of antioxidant enzyme activity, growth and yield of pepper and watermelon plants to a single application of simulated acid rain. J. Food Agric. Environ. 2010, 8, 1265-1271. [CrossRef] 